\title{
Variations in the Toxic Effects of Petroleum Hydrocarbons to Isochrysis galbana under Different Environmental Factors
}

\author{
Jianming Chen \\ Laboratory of Ecology, College of Marine Life Science, Ocean University of China \\ Qingdao 266003, P. R. China
}

Yongqian Li

Laboratory of Ecology, College of Marine Life Science, Ocean University of China Qingdao 266003, P. R. China

Xuexi Tang

Laboratory of Ecology, College of Marine Life Science, Ocean University of China Qingdao 266003, P. R. China

\author{
Hui Xiao (Corresponding author) \\ Laboratory of Ecology, College of Marine Life Science, Ocean University of China \\ Qingdao 266003, P. R. China
}

Received: April 25, 2015

Accepted: May 30, 2015 Published: July 25, 2015

doi:10.5296/ast.v3i2.8051

URL: http://dx.doi.org/10.5296/ast.v3i2.8051

\begin{abstract}
In order to study the toxic effect of petroleum hydrocarbons on marine phytoplankton, Isochrysis galbana was investigated by using the index of 96 h-EC50 and population growth. The results showed that the 96 h-EC50 increased significantly $(\mathrm{P}<0.05)$ when temperature rising from $15^{\circ} \mathrm{C}$ to $25^{\circ} \mathrm{C}$. The intrinsic growth rates $(\mathrm{r})$ increased but the time to enter into the stationary phase shortened from $15^{\circ} \mathrm{C}$ to $25^{\circ} \mathrm{C}$, and the carrying capability $(\mathrm{K})$ reached highest at $20^{\circ} \mathrm{C}$. In addition, the $96 \mathrm{~h}$-EC50 in the salinity of 31 is higher than that in other salinities and the carrying capability reached the highest level. Moreover, the 96 h-EC50 increased when the pH changing from 6.5 to 8.1 , but decreased
\end{abstract}




\section{Macrothink}

Aquatic Science and Technology

ISSN 2168-9148

2015, Vol. 3, No. 2

when the $\mathrm{pH}$ more than 8.1. The results also show that the maximum (K) and (r), and the shortest time into stationary phases in the natural $\mathrm{pH}$ of seawater. It shows the minimum $(\mathrm{K})$ in the low $\mathrm{pH}$ of 6.5. There is no significant $(\mathrm{P}>0.05)$ between $\mathrm{pH} 7.5$ and $\mathrm{pH}$ 8.5. In conclusion, temperature, $\mathrm{pH}$ and salinity did influence the toxicity of petroleum hydrocarbon to the microalgae (I. galbana).

Keywords: Isochrysis galbana, Environmental factors, Petroleum hydrocarbon, Toxic effect 


\section{Introduction}

Nowadays, marine oil pollution has been accelerated by the current economic globalization and has become one of the key issues faced by the government and society. It comes from many ways such as ocean transportation, offshore oil production and the use as a kind of primary fuel. The deepwater horizon oil rig of ConocoPhillips oil spills in June, 2011 was described as an ecological disaster and the greatest oil spills in the history of China. Crude oil is comprised of a complex mixture of petroleum hydrocarbon and non-hydrocarbon compounds (Board, 2003). After the oil spill, the oil was floating on the surface of sea and typically each ton of oil in terms of oil film covering the sea surface range of $12 \mathrm{~km}^{2}$ (Tian, 1999). And it can also be transformed into small molecules dissolved in seawater, which began to spread with the ocean currents and waves push. Therefore, a large area of the barrier film formed and hindered normal air-sea exchange, impact on the physiological and biochemical phytoplankton, which led to the destruction of the ecological balance of oceans in climate anomalies. The main components of WAF were long-chain hydrocarbons, short chain hydrocarbons and few of aromatic hydrocarbons. Studies showed that the most poisonous oil component was small molecular weight PAHs in a short time, which became the primary source of persistent toxicity effects in the area of oil spill (Neff, 1995; Boehm \& Page, 2007; Neff et al., 2000). Studies showed that WAF in seawater poses a significant threat to marine lives, as WAF toxic effects can cascade across the trophic levels. Ecologically, WAF can change the structure and function of both seawater and food webs.

Phytoplanktons are unicellular primary producers, which often referred to as algae-which collectively form the base for the most spatially extensive food webs in nature. Exposed in WAF long-term, physiological and biochemical process of phytoplankton can be altered, organelles damaged, and the growth and reproduction waken. Petroleum hydrocarbons exert toxic effects on marine lives, varying in different environment factors. The toxicity may vary in solubility and structure in water under different temperatures, salinities, $\mathrm{pH}$ values and illumination intensities.

There were various researches on acute toxicity effects of fuel oil and PAHs (Zhang, 2013; $\mathrm{Bi}$, 2015), but the variation of toxic effect of WAF on microalgae under different environmental factors were less.

This article studied the variations of toxicity effects of Isochrysis galbana exposed to WAF in a period of $96 \mathrm{~h}$ and long-term culture under different environmental factors, which will be the base of research on WAF toxicity and offshore oil contamination biological monitoring.

\section{Materials and Methods}

\subsection{Chemicals}

Water-accommodated fraction (WAF): the crude oil comes from Shengli oilfield was mixed with seawater according to the volume ratio 1:9 in a $5 \mathrm{~L}$ glass mixing chamber, stirring for $24 \mathrm{~h}$ with a magnetic stirrer at room temperature. The mother liquor was separated from the mixture water in a separating funnel after 4h's standing, and kept in the brown jars in 
refrigerator $\left(4{ }^{\circ} \mathrm{C}\right)$. The concentration of the mother liquor was determined by UV-spectrophotometer, and diluted it before using it.

\subsection{Organisms}

Isochrysis galbana, a species of marine phytoplankton, was used in this study. It was obtained from the Marine Microalgae Research Center, Ocean University of China.

\subsection{Toxicity Experiments}

To determine the toxicity of WAF on Isochrysis galbana under different environmental factors, we set the WAF concentration series as $0,0.5,2,4,8,16 \mathrm{mg} / \mathrm{L}$. The $0 \mathrm{mg} / \mathrm{L}$ was control, each concentration have three repeats. The initial cell density of the algae was set to $20 \times 10^{4}$ cells $\mathrm{mL}^{-1}$. The algae were grown in closed Erlenmeyer flasks with modified $\mathrm{f} / 2$ media at $20 \pm 1{ }^{\circ} \mathrm{C} 80 \mu \mathrm{mol}$ photon $\mathrm{m}^{-2} \mathrm{~s}^{-1}$ with the light-dark cycle was $12 \mathrm{~h}: 12 \mathrm{~h}$, and waved the conical flask twice a day. The initial $\mathrm{pH}$ and salinity of the culture medium were $8.1 \pm$ 0.02 and 31 , respectively. The experimental volume was $250 \mathrm{ml}$, and a $0.5 \mathrm{ml}$ sample was collected at $24 \mathrm{~h}, 48 \mathrm{~h}, 72 \mathrm{~h}$, and $96 \mathrm{~h}$ to determine the cell density with a haemocytometer and an optional microscope (OlympusCX31, Japan).

Treatment1: Set the temperature of culture medium as $15^{\circ} \mathrm{C}, 20^{\circ} \mathrm{C}, 25^{\circ} \mathrm{C}$, and the initial salinity and $\mathrm{pH}$ as natural seawater level that was $8.1 \pm 0.02$ and 31 ,respectively.

Treatment2: Set the initial salinity of culture medium as $15,25,35$, and the initial $\mathrm{pH}$ was 8.1 \pm 0.02 at $20 \pm 1{ }^{\circ} \mathrm{C}$.

Treatment3: Set the initial $\mathrm{pH}$ of culture medium as $6.5,7.5,8.5$, and the initial salinity was 31 at $20 \pm 1^{\circ} \mathrm{C}$.

\subsection{Monoculture Exposed in WAF}

Preculture the algae during the exponential growth phase. The initial cell density was set as 1 $\times \times 10^{4}$ cells $\mathrm{mL}^{-1}$ for Isochrysis galbana. Treatments of different environmental factors of the culture medium was same as in toxic experiments. The experimental volume was $100 \mathrm{ml}$, and a $0.5 \mathrm{ml}$ sample was collected every two days to determine the cell density with a haemocytometer and an optional microscope (OlympusCX31, Japan).

\subsection{Data Analysis and Statistics}

The experiment data ware In-transformed, and the growth rate of algae fit to the following equation:

$$
\mu_{0-\mathrm{L}}=\left(\operatorname{In} \mathrm{X}_{\mathrm{L}}-\operatorname{In} \mathrm{X}_{0}\right) /\left(\mathrm{t}_{\mathrm{L}}-\mathrm{t}_{0}\right)
$$

Where $\mu_{0-\mathrm{L}}$ is the average specific rate of growth from 0 day to $\mathrm{L}$ day; $\mathrm{X}_{\mathrm{L}}$ stand for the cell density in day $\mathrm{L}$ while $\mathrm{X}_{0}$ means the initial cell density.

The growth inhibition rate was fit to the following equation:

$$
\mathrm{I} \%=\left(\mu_{\mathrm{C}}-\mu_{\mathrm{T}}\right) / \mu_{\mathrm{C}} \times 100 \%
$$


I stand for the average of growth inhibition rate; $\mu_{\mathrm{C}}$ stand for the average specific rate of growth of the control grop; $\mu_{\mathrm{T}}$ stand for the average specific rate of growth of the treatment group.

The linear relationship of growth inhibition and concentration of the natural logarithm was established and the $50 \%$ inhibition concentration was calculated by nonlinear regression with the software called Spss for windows 22.0, which called $96 \mathrm{~h} \mathrm{EC}_{50}$.

To investigate the effect of biomass ratio on carrying capacity, we involved the logistic growth model suit for the population growth curve of Isochrysis galbana. The equation as following:

$$
\mathrm{N}_{\mathrm{t}}=\mathrm{K} /\left(1+\mathrm{e}^{\mathrm{a}-\mathrm{rt}}\right)
$$

$\mathrm{N}_{\mathrm{t}}$ stands for the cell density at time $\mathrm{t}\left(\times 10^{4}\right.$ cells $\left.\mathrm{mL}^{-1}\right)$; $\mathrm{K}$ stands for the carrying capability of the population $\left(\times 10^{4}\right.$ cells $\left.\mathrm{mL}^{-1}\right)$ that defines as maximum sustainable population density (biomass) in a given ecosystem; $t$ stands for the sampling time (d); $r$ stands for the specific growth rate $\left(\mathrm{d}^{-1}\right)$; a stands for the constant determining the initial cell density $\left(\mathrm{N}_{0}\right)$.

Estimated values of growth parameters were obtained by the nonlinear regression in SPSS for windows 22.0. It was also conducted to analyze the different in both of $96 \mathrm{~h} \mathrm{EC}_{50}$ and growth parameters among different environmental factors, with the significance level of $\mathrm{P}<0.05$ and extremely significance level of $\mathrm{P}<0.01$.

\section{Results}

\subsection{Variations of the $96 h$ EC50 of WAF for I. galbana under Different Environmental Factors}

The figure 1 shows that the $96 \mathrm{~h} \mathrm{EC}_{50}$ of WAF for Isochrysis galbana switching with the temperature from 15 to 25 were $6.674 \pm 1.096 \mathrm{mg} / \mathrm{L}, \quad 47.097 \pm 2.224 \mathrm{mg} / \mathrm{L}$ and $78.369 \pm 2.518 \mathrm{mg} / \mathrm{L}$ respectively. It meant that the WAF toxic effect on I. galbana decreased significantly with the increase of the temperature.

In addition, the results also indicates that the $96 \mathrm{~h}_{50}$ value of WAF were at a low level and have no significant variation during the salinity of 15 to 25 , which was $24.416 \pm 1.845 \mathrm{mg} / \mathrm{L}$ in the salinity of 15 and $21.437 \pm 1.770 \mathrm{mg} / \mathrm{L}$ in the salinity of 25 . In the salinity of 31 , the $96 \mathrm{~h}$ $\mathrm{EC}_{50}$ of WAF value was $47.097 \pm 2.224 \mathrm{mg} / \mathrm{L}$. It went up significantly $(\mathrm{P}<0.05)$ with the salinity increasing during the salinity of 25 to 31 , but dropped with the continuous increase of the salinity. In the salinity of 35 , the $96 \mathrm{~h} \mathrm{EC}_{50}$ value of WAF was $35.437 \pm 2.060 \mathrm{mg} / \mathrm{L}$.

Moreover, the results suggests that the $96 \mathrm{~h} \mathrm{EC}_{50}$ value of WAF mounted with the $\mathrm{pH}$ rising from 6.5 to 8.1 but decreased with the $\mathrm{pH}$ continuing rising. When the initial $\mathrm{pH}$ of the culture mediums was $6.5,7.5$ and 8.5 respectively, the $96 \mathrm{~h}$ EC50 values of WAF were $18.433 \pm 2.91 \mathrm{mg} / \mathrm{L}, 21.916 \pm 3.087 \mathrm{mg} / \mathrm{L}$ and $33.124 \pm 3.500 \mathrm{mg} / \mathrm{L}$ respectively. At the natural seawater $\mathrm{pH}$ level $(8.1)$, the $96 \mathrm{~h}_{50}$ values of WAF reached $47.097 \pm 2.224 \mathrm{mg} / \mathrm{L}$. Both of low and high level of the initial $\mathrm{pH}$ decreased the $96 \mathrm{~h} \mathrm{EC}_{50}$ values of WAF. 

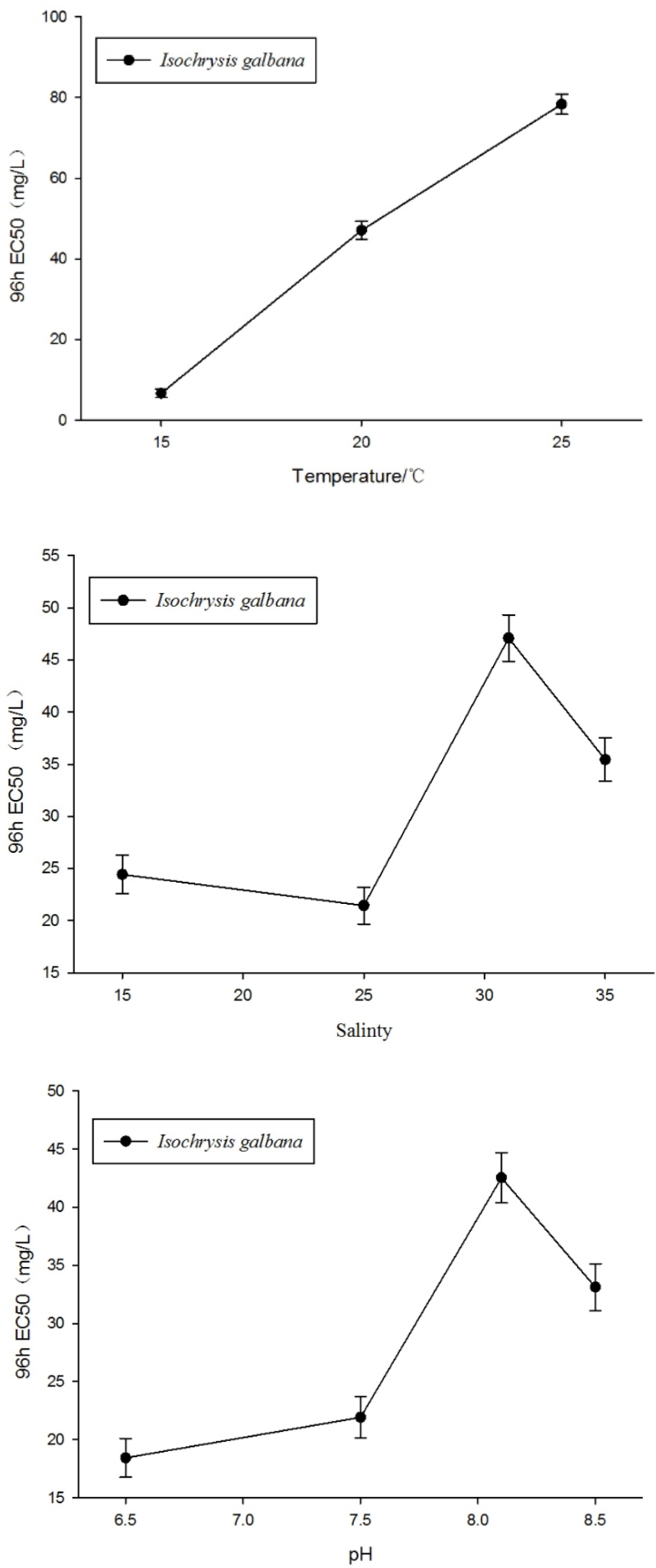

Figure 1. The 96h WAF $\mathrm{EC}_{50}$ on Isochrysis galbana under different environmental factors 
3.2 Variations of the Population Growth of I. galbana Exposed to WAF under Different Environmental Factors

Table1, table 2 and table 3 listed Variations of the population growth of I. galbana exposed to $\mathrm{WAF}$ at different temperature, salinity and $\mathrm{pH}$ respectively.

Firstly, from table 1,it is clear that the maximum of sustainable population density $(\mathrm{K})$ reached to the highest value in $20^{\circ} \mathrm{C}$ at each concentration of WAF and there is a sharp drop at low temperature of $15^{\circ} \mathrm{C}(\mathrm{P}<0.05)$. The intrinsic rate of population growth was increased significantly with the temperature increasing $(\mathrm{P}<0.05)$. For the time to reach the platform, it showed shorter at a higher temperature expect the control and $0.5 \mathrm{mg} / \mathrm{L}$ groups.

Table 1. The parameters, regression coefficient $\left(\mathrm{R}^{2}\right)$ and the reflection point of Logistic equation of I. galbana cultured in different density of WAF under different temperatures

\begin{tabular}{lllllll}
\hline $\mathbf{W A F}(\mathbf{m g} / \mathbf{L})$ & $\mathbf{T}\left({ }^{\circ} \mathbf{C}\right)$ & $\mathbf{K}$ & $\mathbf{a}$ & $\mathbf{r} / \mathbf{d}^{\mathbf{1}}$ & $\mathbf{R}^{\mathbf{2}}$ & $\mathbf{T} \mathbf{p}(\mathbf{d})$ \\
\hline $\mathbf{0}$ & 15 & $766.840 \pm 21.005$ & $5.002 \pm 0.198$ & $0.518 \pm 0.038$ & 0.997 & 9.7 \\
& 20 & $1096.990 \pm 81.523$ & $4.385 \pm 0.166$ & $0.444 \pm 0.036$ & 0.996 & 9.9 \\
& 25 & $1065.856 \pm 19.122$ & $5.227 \pm 0.091$ & $0.598 \pm 0.025$ & 0.991 & 8.7 \\
\hline $\mathbf{0 . 5}$ & 15 & $724.758 \pm 34.968$ & $4.670 \pm 0.130$ & $0.491 \pm 0.034$ & 0.994 & 9.5 \\
& 20 & $1058.975 \pm 46.692$ & $4.564 \pm 0.090$ & $0.468 \pm 0.021$ & 0.996 & 9.8 \\
& 25 & $1016.128 \pm 19.433$ & $5.283 \pm 0.132$ & $0.629 \pm 0.014$ & 0.995 & 8.4 \\
\hline $\mathbf{2}$ & 15 & $703.682 \pm 12.505$ & $4.617 \pm 0.072$ & $0.472 \pm 0.018$ & 0.992 & 9.8 \\
& 20 & $949.166 \pm 30.315$ & $4.904 \pm 0.299$ & $0.518 \pm 0.038$ & 0.996 & 9.5 \\
& 25 & $931.717 \pm 32.435$ & $5.774 \pm 0.451$ & $0.700 \pm 0.068$ & 1.000 & 8.2 \\
\hline $\mathbf{4}$ & 15 & $676.638 \pm 45.669$ & $4.674 \pm 0.127$ & $0.454 \pm 0.038$ & 0.995 & 10.3 \\
& 20 & $884.940 \pm 19.204$ & $5.095 \pm 0.250$ & $0.533 \pm 0.034$ & 0.989 & 9.6 \\
& 25 & $863.270 \pm 18.554$ & $5.978 \pm 0.133$ & $0.727 \pm 0.021$ & 0.999 & 8.2 \\
\hline $\mathbf{8}$ & 15 & $623.354 \pm 12.874$ & $4.873 \pm 0.077$ & $0.434 \pm 0.022$ & 0.993 & 11.2 \\
& 20 & $838.556 \pm 23.786$ & $5.322 \pm 0.093$ & $0.547 \pm 0.006$ & 0.998 & 9.7 \\
& 25 & $814.460 \pm 24.500$ & $6.102 \pm 0.267$ & $0.726 \pm 0.031$ & 0.997 & 8.4 \\
\hline $\mathbf{1 6}$ & 15 & $558.027 \pm 38.839$ & $5.199 \pm 0.198$ & $0.445 \pm 0.037$ & 0.996 & 11.7 \\
& 20 & $792.283 \pm 24.163$ & $5.314 \pm 0.406$ & $0.520 \pm 0.044$ & 0.999 & 10.2 \\
& 25 & $759.908 \pm 7.737$ & $6.229 \pm 0.033$ & $0.713 \pm 0.005$ & 0.998 & 8.7 \\
\hline
\end{tabular}

Secondly, As is shown in the table 2, the maximum of sustainable population density (K) was highest in the salinity of 31 , either higher or lower salinities resulted the lower value. The results show the different carrying capabilities $(\mathrm{K})$, intrinsic growth rates (r) and the timings into stationary phases in different salinities. It shows the maximum $\mathrm{K}$ and $\mathrm{r}$, and the shortest time into stationary phases of $I$. galbana exposed in WAF in the natural salinity of seawater. Both of the lower and the higher salinity make the opposite results. 
Table 2. The parameters, regression coefficient $\left(\mathrm{R}^{2}\right)$ and the reflection point of Logistic equation of I. galbana cultured in different density of WAF under different salinities

\begin{tabular}{|c|c|c|c|c|c|c|}
\hline WAF (mg/L) & salinity & $\mathbf{K}$ & $\mathbf{a}$ & $\mathbf{r}$ & $\mathbf{R}^{2}$ & $T p(d)$ \\
\hline \multirow[t]{4}{*}{ 0 } & 15 & $906.353 \pm 22.106$ & $5.332 \pm 0.186$ & $0.595 \pm 0.03$ & 0.9960 & 9.0 \\
\hline & 25 & $1064.048 \pm 50.606$ & $5.025 \pm 0.162$ & $0.604 \pm 0.041$ & 0.9968 & 8.3 \\
\hline & 31 & $1096.99 \pm 81.523$ & $4.385 \pm 0.166$ & $0.444 \pm 0.036$ & 0.9961 & 9.9 \\
\hline & 35 & $1043.025 \pm 41.021$ & $5.459 \pm 0.057$ & $0.619 \pm 0.018$ & 0.9991 & 8.8 \\
\hline \multirow[t]{4}{*}{0.5} & 15 & $891.641 \pm 20.567$ & $5.666 \pm 0.315$ & $0.636 \pm 0.045$ & 0.9960 & 8.9 \\
\hline & 25 & $1021.386 \pm 8.923$ & $5.341 \pm 0.031$ & $0.662 \pm 0.008$ & 0.9985 & 8.1 \\
\hline & 31 & $1058.976 \pm 46.692$ & $4.564 \pm 0.090$ & $0.468 \pm 0.021$ & 0.9974 & 9.8 \\
\hline & 35 & $1008.042 \pm 17.716$ & $5.940 \pm 0.154$ & $0.682 \pm 0.025$ & 0.9979 & 8.7 \\
\hline \multirow[t]{4}{*}{2} & 15 & $892.977 \pm 17.788$ & $5.439 \pm 0.409$ & $0.586 \pm 0.048$ & 0.9960 & 9.3 \\
\hline & 25 & $950.275 \pm 12.87$ & $5.781 \pm 0.242$ & $0.726 \pm 0.029$ & 0.9979 & 8.0 \\
\hline & 31 & $949.166 \pm 30.315$ & $4.904 \pm 0.299$ & $0.518 \pm 0.038$ & 0.9977 & 9.5 \\
\hline & 35 & $934.537 \pm 12.712$ & $6.368 \pm 0.288$ & $0.739 \pm 0.03$ & 0.9982 & 8.6 \\
\hline \multirow[t]{4}{*}{4} & 15 & $818.435 \pm 22.158$ & $5.644 \pm 0.145$ & $0.608 \pm 0.018$ & 0.9890 & 9.3 \\
\hline & 25 & $873.21 \pm 20.325$ & $6.296 \pm 0.231$ & $0.794 \pm 0.045$ & 0.9988 & 7.9 \\
\hline & 31 & $884.94 \pm 19.204$ & $5.095 \pm 0.250$ & $0.533 \pm 0.034$ & 0.9981 & 9.6 \\
\hline & 35 & $878.205 \pm 19.602$ & $6.988 \pm 0.235$ & $0.807 \pm 0.04$ & 0.9980 & 8.7 \\
\hline \multirow[t]{4}{*}{8} & 15 & $772.444 \pm 9.678$ & $5.839 \pm 0.162$ & $0.616 \pm 0.014$ & 0.9980 & 9.5 \\
\hline & 25 & $799.086 \pm 10.155$ & $6.474 \pm 0.327$ & $0.814 \pm 0.053$ & 0.9978 & 8.0 \\
\hline & 31 & $838.556 \pm 23.786$ & $5.322 \pm 0.093$ & $0.547 \pm 0.006$ & 0.9974 & 9.7 \\
\hline & 35 & $808.156 \pm 3.512$ & $7.05 \pm 0.151$ & $0.807 \pm 0.025$ & 0.9978 & 8.7 \\
\hline \multirow[t]{4}{*}{16} & 15 & $690.917 \pm 8.096$ & $5.983 \pm 0.437$ & $0.589 \pm 0.052$ & 0.999 & 10.2 \\
\hline & 25 & $652.567 \pm 16.833$ & $6.25 \pm 0.191$ & $0.715 \pm 0.02$ & 0.9924 & 8.7 \\
\hline & 31 & $792.283 \pm 24.163$ & $5.314 \pm 0.406$ & $0.52 \pm 0.044$ & 0.9832 & 10.2 \\
\hline & 35 & $656.346 \pm 19.982$ & $5.938 \pm 0.287$ & $0.658 \pm 0.025$ & 0.9993 & 9.0 \\
\hline
\end{tabular}

Finally, the table 3 shows that the maximum of sustainable population density (K) was highest in the initial $\mathrm{pH}$ of 8.1, either higher or lower $\mathrm{pH}$ resulted in the lower value of K.It is apparent that the $\mathrm{K}$ in groups of the initial $\mathrm{pH}$ of 6.5 declined sharply than other levels of $\mathrm{pH}$ groups. The results show the maximum $(\mathrm{K})$ and $(\mathrm{r})$, and the shortest time into stationary phases in the natural $\mathrm{pH}$ of seawater. It is clear that the minimum $(\mathrm{K})$ in the low $\mathrm{pH}$ of 6.5 .

From above data, it can be seen that the environmental factors change the toxic effect of WAF on Isochysis galbana in population growth. 
Table 3. The parameters, regression coefficient $\left(\mathrm{R}^{2}\right)$ and the reflection point of Logistic equation of I. galbana cultured in different density of WAF under different $\mathrm{pH}$

\begin{tabular}{|c|c|c|c|c|c|c|}
\hline WAF (mg/L) & pH & $\mathbf{K}$ & $\mathbf{a}$ & $\mathbf{r} / \mathbf{d}^{-1}$ & $\mathbf{R}^{2}$ & Tp (d) \\
\hline \multirow[t]{4}{*}{$\mathbf{0}$} & 6.5 & $783.281 \pm 6.495$ & $5.321 \pm 0.39$ & $0.537 \pm 0.043$ & 0.9963 & 9.9 \\
\hline & 7.5 & $1012.252 \pm 69.098$ & $5.063 \pm 0.213$ & $0.507 \pm 0.036$ & 0.9948 & 10 \\
\hline & 8.1 & $1096.99 \pm 81.523$ & $4.385 \pm 0.166$ & $0.444 \pm 0.036$ & 0.9899 & 9.9 \\
\hline & 8.5 & $1021.532 \pm 70.694$ & $5.053 \pm 0.338$ & $0.529 \pm 0.056$ & 0.9882 & 9.6 \\
\hline \multirow[t]{4}{*}{0.5} & 6.5 & $760.208 \pm 12.977$ & $5.158 \pm 0.153$ & $0.519 \pm 0.013$ & 0.9958 & 9.9 \\
\hline & 7.5 & $984.997 \pm 45.685$ & $5.286 \pm 0.377$ & $0.538 \pm 0.05$ & 0.9954 & 9.8 \\
\hline & 8.1 & $1058.976 \pm 46.692$ & $4.564 \pm 0.09$ & $0.468 \pm 0.021$ & 0.9889 & 9.8 \\
\hline & 8.5 & $987.2 \pm 38.648$ & $5.298 \pm 0.169$ & $0.561 \pm 0.029$ & 0.9866 & 9.4 \\
\hline \multirow[t]{4}{*}{2} & 6.5 & $726.737 \pm 26.229$ & $5.154 \pm 0.284$ & $0.504 \pm 0.013$ & 0.9934 & 10.2 \\
\hline & 7.5 & $894.59 \pm 26.073$ & $5.778 \pm 0.262$ & $0.602 \pm 0.034$ & 0.9987 & 9.6 \\
\hline & 8.1 & $949.166 \pm 30.315$ & $4.904 \pm 0.299$ & $0.518 \pm 0.038$ & 0.9939 & 9.5 \\
\hline & 8.5 & $920.307 \pm 26.959$ & $5.602 \pm 0.407$ & $0.598 \pm 0.049$ & 0.9957 & 9.4 \\
\hline \multirow[t]{4}{*}{4} & 6.5 & $660.445 \pm 11.119$ & $5.02 \pm 0.322$ & $0.491 \pm 0.031$ & 0.9981 & 10.2 \\
\hline & 7.5 & $833.387 \pm 17.88$ & $6.092 \pm 0.473$ & $0.629 \pm 0.051$ & 0.9981 & 9.7 \\
\hline & 8.1 & $884.94 \pm 19.204$ & $5.095 \pm 0.25$ & $0.533 \pm 0.034$ & 0.998 & 9.6 \\
\hline & 8.5 & $835.432 \pm 22.853$ & $5.334 \pm 0.3$ & $0.569 \pm 0.042$ & 0.997 & 9.4 \\
\hline \multirow[t]{4}{*}{8} & 6.5 & $583.975 \pm 14.716$ & $4.97 \pm 0.151$ & $0.456 \pm 0.026$ & 0.9943 & 10.9 \\
\hline & 7.5 & $793.547 \pm 23.966$ & $6.696 \pm 0.05$ & $0.678 \pm 0.009$ & 0.9993 & 9.9 \\
\hline & 8.1 & $838.556 \pm 23.786$ & $5.322 \pm 0.093$ & $0.547 \pm 0.006$ & 0.9979 & 9.7 \\
\hline & 8.5 & $790.06 \pm 20.869$ & $5.211 \pm 0.139$ & $0.543 \pm 0.011$ & 0.9971 & 9.6 \\
\hline \multirow[t]{4}{*}{16} & 6.5 & $527.259 \pm 12.869$ & $5.365 \pm 0.566$ & $0.47 \pm 0.054$ & 0.9957 & 11.4 \\
\hline & 7.5 & $765.929 \pm 25.601$ & $6.309 \pm 0.637$ & $0.602 \pm 0.067$ & 0.9991 & 10.5 \\
\hline & 8.1 & $792.283 \pm 24.163$ & $5.314 \pm 0.406$ & $0.52 \pm 0.044$ & 0.999 & 10.2 \\
\hline & 8.5 & $762.425 \pm 28.963$ & $5.088 \pm 0.447$ & $0.489 \pm 0.049$ & 0.9985 & 10.4 \\
\hline
\end{tabular}

\section{Discussion}

It has been well known that WAF effects on the growth and reproduction of algae (Gaur et al., 1981; Pérez et al., 2010; Jiang et al., 2012). In this study, the WAF 96h $\mathrm{EC}_{50}$ values on $I$. 
galbana varied under different environmental factors, which phenomenon meant the variations of WAF toxic effect. The result showed a high toxicity of WAF in Fig. 1 at low temperature of $15^{\circ} \mathrm{C}$.

At present, studies have shown that the effect of temperature fluctuation in the growth, physiological and biochemical characteristics of marine microalgae. The most important parts of the cell membrane damage effects, the primary reaction injury at low temperature during phase transition lipid molecules on biofilm systems (Gong et al., 2001). Another research shows that the active cryogenic oxygen plants metabolic balance is broken, keeping up with the rate of degradation of the active oxygen species generated. Therefore, some researchers pointed out that the damage caused by low temperature membrane system may related with free radicals and reactive oxygen on membrane lipid peroxidation and protein oxidative damage. The cell electrolyte leakage and membrane peroxidation increased and membrane permeability-increasing at low temperature. Therefore, the WAF components may enter into the cell easier at low temperature. It showed in Tab.1 that the population growth of I. galbana exposed in WAF was also influenced by the variation of temperature.

Salinity is one of the most important environmental factors. In this study, both the low and high levels of salinities lead to higher WAF toxicity, but showed a low toxicity in the salinity of natural seawater. Salt stress can lead to excessive production of ROS, causing oxidative damage to cells (Choo et al. 2004). ROS cause lipid peroxidation, the increase of MDA concentration peroxide generated content may reflect the rise of ROS (Tang et al., 2007). Thus, both low and high salinities make WAF poison the algae easier than in natural salinity.

The $\mathrm{pH}$ of offshore seawater was unsustainable result in human behavior and absolutely lower than in ocean. In this study, results showed a significant increase of WAF toxicity in low $\mathrm{pH}$ value. Studies indicated that may severely affect the photosynthesis of algae once $\mathrm{pH}$ value beyond the certain range (Ansari et al., 2015). Some studies have concluded that higher hydrogen ion content by algae cell membrane penetration to the interior of the cell in low $\mathrm{pH}$ value environment, so that a number of intracellular enzymes can be lowered the activity inactivation. Therefore, I. galbana has a lower tolerance to WAF in low $\mathrm{pH}$ value environment, and strengthens the toxicity of WAF.

\section{Conclusions}

From the analysis above, we can conclude that the WAF toxicity to I. galbana varied with the variations of the environmental factors. In the range of experiment, while the toxicity of WAF was weakened with the rising of temperature, both high and low levels of salinities and $\mathrm{pH}$ enhanced the toxicity of WAF.

\section{Acknowledgements}

Funding was provided by "Opening fund of the State Oceanic Administration Key Laboratory of Marine Spill Oil Identification and Damage Assessment Technology (201108).” 


\section{References}

Ansari, O., \& Colman, B. (2015). Inorganic carbon acquisition in the acid - tolerant alga Chlorella kessleri. Physiologia plantarum, 153(1), 175-182. http://dx.doi.org/10.1111/ppl.12228

Bi, R., Wang, Y., Wang, R., et al. (2015). Effect of anthracene on the interaction between Platymonas helgolandica var. tsingtaoensis and Heterosigma akashiwo in laboratory cultures. Journal of Ocean University of China, 14(1), 105-113. http://dx.doi.org/10.1007/s11802-015-2345-2

Board, M., \& Board, O. S. (2003). Oil in the Sea III: Inputs, Fates, and Effects. National academies Press.

Boehm, P. D., \& Page, D. S. (2007). Exposure elements in oil spill risk and natural resource damage assessments: a review. Hum. Ecol. Risk. Assess., 13, 418-448. http://dx.doi.org/10.1080/10807030701226293

Choo, K. S., Snoeijs, P., \& Pedersen, M. (2004). Oxidative stress tolerance in the filamentous green algae CladopHora glomerata and EnteromorpHa ahlneriana. Journal of Experimental Marine Biology and Ecology, 298, 111-123. http://dx.doi.org/10.1016/j.jembe.2003.08.007

Deng, G., Li, Y.-G., Hu, H.-J., Qi, Y.-Z., Geng, Y.-H., Li, Z.-K. (2004). Effects of temperature, light and $\mathrm{pH}$ on photosynthesis, and of light-dark cycle on growth rate and biomass of scrippsiella trochoidea and alexandrium tamarense. Journal of Wuhan Botanical Research, 22(2), 129-135.

Gaur, J. P., \& Kumar, H. D. (1981). Growth response of four micro-algae to three crude oils and a furnace oil. Environmental Pollution Series A, Ecological and Biological, 25(1), 77-85. http://dx.doi.org/10.1016/0143-1471(81)90116-1

Gong, X.-Z., Tang, X.-X., Huang, J., Zhang, X.-C., Yang, Z., \& Zhang, K.-S. (2001). Mechanism of low temperature tolerance of Isochrysis galbana Parke 8701. Journal Of Fisheries Of China, 25(1), 20-25.

Jiang, Z., Huang, Y., Chen, Q., et al. (2012). Acute toxicity of crude oil water accommodated fraction on marine copepods: the relative importance of acclimatization temperature and body $\begin{array}{llll}\text { size. } & \text { Marine } & \text { Environmental } & \text { Research, }\end{array}$ http://dx.doi.org/10.1016/j.marenvres.2012.08.003

Neff, J. M., \& Stubblefield, W. A. (1995). Exxon Valdez Oil Spill: Fate and Effects in Alaskan Waters, ASTM STP 1219, p. 141.

Neff, J. M., Ostazeski, S., Gardiner, W., \& Stejskal, I. (2000). Effects of weathering on the toxicity of three offshore Australian crude oils and a diesel fuel to marine animals. Environ. Toxicol. Chem., 19, 1809-1821. http://dx.doi.org/10.1002/etc.5620190715

Skowroński, T., Szubińska, S., Pawlik B., et al. (1991). The influence of pH on cadmium toxicity to the green alga Stichococcus bacillaris and on the cadmium forms present in the 


\section{Mll Macrothink}

Aquatic Science and Technology

ISSN 2168-9148 2015, Vol. 3, No. 2

$\begin{array}{llll}\text { culture medium. } & \text { Environmental } & \text { Pollution, } & \text { 74(2), }\end{array}$ http://dx.doi.org/10.1016/0269-7491(91)90106-7

Tang, D., Shi, S., Li, D., Hu, C., \& Liu, Y. (2007). Physiological and biochemical responses of Scytonema javanicum (cyanobacterium) to salt stress. Journal of Arid Environments, 71, 312-322. http://dx.doi.org/10.1016/j.jaridenv.2007.05.004

Tian, L.-J., \& Zhang, R.-A. (1999). The effect of offshore oil pollution on marine ecological environment. Transactions of Oceanology and Limnology, 2, 65-69.

Zhang, Y. B., \& Tang, X. X. (2013). Effect of Oil Water-Accommodated Fraction on Growth and Chlorophyll-A of Marine Microalgae. Advanced Materials Research, 726, 94-97. http://dx.doi.org/10.4028/www.scientific.net/amr.726-731.94

\section{Copyright Disclaimer}

Copyright for this article is retained by the author(s), with first publication rights granted to the journal.

This is an open-access article distributed under the terms and conditions of the Creative Commons Attribution license (http://creativecommons.org/licenses/by/3.0/). 